6 Parsons L, Richards J, Garlick R. Screening for Down's syndrome. BMJ 1992;305:1228

7 Cockburn J, Redman S, Hill D, Henry E. Public understanding of medical screening. J Med Screen 1995;2:224-7.

8 Smith DK, Shaw RW, Marteau T. Informed consent to undergo serum screening for Down's syndrome: the gap between policy and practice. BMJ 1994;309:776.

9 Hall S, Bobrow M, Marteau TM. Parents attributions of blame for the birth of a child with Down syndrome: a pilot study. Psychol Health 1997;12:579-87

10 Tennen H, Affleck G. Blaming others for threatening events. Psychol Bull $1990 ; 108: 209-32$

11 Mutton DE, Alberman E, Ide R, Bobrow M. Results of first year (1989) of a national register of Down's syndrome in England and Wales. BMJ $1991 \cdot 303: 1295-7$

12 Mutton DE, Ide R, Alberman E, Bobrow M. Analysis of national register of Down's syndrome in England and Wales: trends in prenatal diagnosis, 1989-91. BMJ 1993;306:431-2

13 Marteau TM, Bekker H. Development of a short-form of the state scale of the Spielberger state-trait anxiety inventory. Br J Clin Psychol 1992;31:301-6.
14 Judson SL, Burden RL. Towards a tailored measure of parental attitudes: an approach to the evaluation of one aspect of intervention projects with parents of handicapped children. Child Care Health Dev 1980;6: 47-55.

15 Radloff L. CES-D scale: a self-report depression scale for research in the general population. Appl Psychosoc Measurement 1977;1:385-40.

16 Abidin RR. Parenting stress index (short form): test manual. Charlottesville, VA: Pediatric Psychology Press, 1990.

17 Quine L, Phal J. Stress and coping in mothers caring for a child with severe learning difficulties: a test of Lazarus' transactional model of coping. J Community Appl Soc Psychol 1991;1:57-90.

18 Gardner SB, Winter PD, Altman, DG. Statistics with confidence. London: BMJ Publishing, 1989.

19 Marteau TM, Slack J, Kidd J, Shaw RW. Presenting a routine screening test in antenatal care: practice observed. Public Health 1992;106:131-41.

20 Allanson A, Michie S, Marteau TM. Presentation of screen negative results on serum screening for Down syndrome: variations across Britain. J Med Screen 1997;4:21-2.

(Accepted 29 November 1999)

\title{
Exposure to foodborne and orofecal microbes versus airborne viruses in relation to atopy and allergic asthma: epidemiological study
}

Paolo M Matricardi, Francesco Rosmini, Silvia Riondino, Michele Fortini, Luigina Ferrigno, Maria Rapicetta, Sergio Bonini

\section{Laboratorio di Immunologia ed Allergologia, Divisione Aerea Studi Ricerche e Sperimentazioni 00040 Pomezia, \\ Rome, Italy \\ Paolo M Matricardi research director \\ Silvia Riondino research fellow Michele Fortini research assistant \\ Laboratorio di Epidemiologia e Biostatistica, Istituto Superiore di Sanita, Rome, Italy \\ Francesco Rosmin scientist \\ Luiginia Ferrigno research assistant \\ Laboratorio di Virologia, Istituto Superiore di Sanita \\ Maria Rapicetta research director \\ Istituto di Medicina Sperimentale, Consiglio Nazionale delle Ricerche, \\ Rome, Italy \\ Sergio Bonini \\ research unit director \\ Correspondence to: P M Matricardi matricardi.pm@ mclink.it}

BMJ 2000;320:412-7

\begin{abstract}
Objective To investigate if markers of exposure to foodborne and orofecal microbes versus airborne viruses are associated with atopy and respiratory allergies.

Design Retrospective case-control study. Participants 240 atopic cases and 240 non-atopic controls from a population sample of 1659 participants, all Italian male cadets aged 17-24. Setting Air force school in Caserta, Italy. Main outcome measures Serology for Toxoplasma gondii, Helicobacter pylori, hepatitis A virus, measles, mumps, rubella, chickenpox, cytomegalovirus, and herpes simplex virus type 1 ; skin sensitisation and $\operatorname{IgE}$ antibodies to relevant airborne allergens; total IgE concentration; and diagnosis of allergic asthma or rhinitis.

Results Compared with controls there was a lower prevalence of $T$ gondii $(26 \% v 18 \%, \mathrm{P}=0.027)$, hepatitis A virus $(30 \% v 16 \%, \mathrm{P}=0.004)$, and $H$ pylori $(18 \%$ v $15 \%, \mathrm{P}=0.325)$ in atopic participants. Adjusted odds ratios of atopy decreased with a gradient of exposure to $H$ pylori, $T$ gondii, and hepatitis A virus (none, odds ratio 1; one, 0.70; two or three, 0.37; $\mathrm{P}$ for trend $=0.000045$ ) but not with cumulative exposure to the other viruses. Conversely, total IgE concentration was not independently associated with any infection. Allergic asthma was rare $(1 / 245,0.4 \%)$ and allergic rhinitis infrequent $(16 / 245$, $7 \%)$ among the participants $(245 / 1659)$ exposed to at least two orofecal and foodborne infections (H pylori, $T$ gondii, hepatitis A virus).
\end{abstract}

Conclusion Respiratory allergy is less frequent in people heavily exposed to orofecal and foodborne microbes. Hygiene and a westernised, semisterile diet may facilitate atopy by influencing the overall pattern of commensals and pathogens that stimulate the gut associated lymphoid tissue thus contributing to the epidemic of allergic asthma and rhinitis in developed countries.

\section{Introduction}

The theory that some infections in early childhood may prevent atopic sensitisation (the "hygiene hypothesis" $)^{1-3}$ is hotly debated. ${ }^{4}$ Initial evidence that some airborne infections exert a "protective" effect ${ }^{5-7}$ was not reproduced. ${ }^{8-11}$ These inconsistencies may reflect differences in population samples and methodologies, or the infections that prevent atopy may include others not examined in those studies. ${ }^{12}$ We previously reported that atopy in Italian military cadets was inversely related to seropositivity for hepatitis A virus, a marker of high exposure to orofecal microbes. ${ }^{13}$ That observation, recently reproduced in a general population sample ${ }^{14}$ was consistent with the hygiene hypothesis and with experimental models suggesting that adequate stimulation of the gut associated lymphoid tissue is necessary to avoid atopic sensitisation to environmental allergens. ${ }^{32}{ }^{12-16}$ If this was true then other markers of orofecal and foodborne infections, besides hepatitis A virus, rather than markers of airborne viral infection should be inversely associated with atopy at population level. To test this working hypothesis we extended our survey on military cadets by examining the relation of atopy, concentration of total IgE, and respiratory allergy with seropositivity to eight other microbes-two microbes mainly carried by food or transmitted by the orofecal route (Toxoplasma gondii, Helicobacter pylori) and six viruses transmitted by other routes, mainly airborne (measles, mumps, rubella, chickenpox, cytomegalovirus, and herpes simplex virus type 1). 


\section{Participants and methods}

\section{Study population}

The study population is described in detail elsewhere. $^{317}$ Briefly, between October 1990 and June 1991 we obtained informed consent from, and examined, 1887 military cadets attending the air force officers' school in Caserta, southern Italy. We recorded details on date of birth, number of older and younger siblings, paternal education, residence, and smoking habit. Lifetime allergic rhinitis or asthma was diagnosed from the results of a standard questionnaire, interview, physical examination, and skin tests as previously reported. ${ }^{13}{ }^{17}$ The present study was completed by 1659 of the 1887 (87.9\%) participants. The study design was approved by the review board authorities of the Italian armed forces.

\section{Skin tests}

Seven airborne allergens (mixed grass, Parietaria judaica, Artemisia vulgaris, Olea europaea, Alternaria alternata, Dermatophagoides pteronyssinus, and cat) were used for skin testing (Standard Quality line, Pharmacia, Uppsala, Sweden) as previously reported..$^{13}$

\section{Testing for IgE}

The concentration of total $\mathrm{IgE}$ was determined with a commercial assay (CAP-IgE FEIA, Pharmacia) in serum samples stored at $-70^{\circ} \mathrm{C}$. The overall degree of IgE sensitisation to inhalant allergens was evaluated with a multiallergen immunoassay (Phadiatop-CAP, Pharmacia $)^{17}$ and expressed as the logarithm of ratio units (logRU) so calculated: $\log \mathrm{RU}=\log$ (fluorescence units in sample/fluorescence units in reference serum). Accordingly, atopy was arbitrarily labelled "high" ( $\operatorname{logRU} \geqslant 1.2,267$ participants), "low" (0-1.19, 296), or "absent" $(<0,1096) .{ }^{13}$ Generally, participants with high atopy corresponded to those with allergic rhinitis or asthma (referred to as "atopic" in this article) ${ }^{13}{ }^{17}$ Most participants with low atopy had detectable but clinically irrelevant concentrations of specific $\operatorname{IgE} .{ }^{17}$

\section{Study design}

We randomly extracted 240 cases and 240 controls from the 267 participants with high atopy and the 1096 non-atopic participants respectively. Within each group there were no major sociodemographic differences between selected and non-selected participants. Serum samples of both groups were tested for IgG antibodies to measles, mumps, rubella, chickenpox, herpes simplex virus type 1 , cytomegalovirus, $T$ gondii, and $H$ pylori chosen according to the following criteria: persistent antibody titres after infection, prevalence $>10 \%$, acquisition usually in early life, no confounding effect from immunisation, and route of transmission known. We also tested the remaining 1179 participants, not included in the case-control analysis, for IgG antibodies against $T$ gondii and $H$ pylori.

\section{Antibodies against microbial agents}

Total antihepatitis A virus antibodies had been previously determined in the whole population sample with a commercial assay (HABA, Abbott, IL). ${ }^{13}$ Antibodies (IgG) against measles, mumps, rubella, chickenpox, herpes simplex virus type 1 , cytomegalovi-
Table 1 Prevalence of antibodies against selected infectious agents in 240 atopic and 240 non-atopic Italian military cadets. Values are numbers (percentages) of participants unless stated otherwise

\begin{tabular}{llll}
\begin{tabular}{l} 
Infectious agent \\
\hline Orofecal and foodborne infections \\
group
\end{tabular} & $\begin{array}{c}\text { Non-atopic } \\
\text { group }\end{array}$ & $\begin{array}{c}\text { Crude odds ratio } \\
\text { (95\% CI) }\end{array}$ \\
\hline Toxoplasma gondii & $63(26)$ & $42(18)^{\star}$ & $0.60(0.38$ to 0.93) \\
\hline Helicobacter pylori & $44(18)$ & $35(15)$ & $0.76(0.47$ to 1.24$)$ \\
\hline Hepatitis A virus & $73(30)$ & $39(16) \dagger$ & $0.44(0.29$ to 0.69$)$ \\
\hline
\end{tabular}

Infections transmitted by other routes

\begin{tabular}{llll}
\hline Measles & $233(97)$ & $231(96)$ & $0.77(0.28$ to 2.11$)$ \\
\hline
\end{tabular}

\begin{tabular}{llll}
\hline Mumps & $92(38)$ & $112(47)$ & $1.41(0.98$ to 2.03)
\end{tabular}

\begin{tabular}{llll}
\hline Rubella & $211(88)$ & $198(83)$ & $0.65(0.39$ to 1.08$)$ \\
\hline
\end{tabular}

\begin{tabular}{llll}
\hline Chickenpox & $157(65)$ & $157(65)$ & $1.00(0.69$ to 1.46$)$ \\
\hline
\end{tabular}

Cytomegalovirus $112(47) \quad 132(55) \quad 1.40(0.97$ to 2.00$)$

\begin{tabular}{llll}
\hline Herpes simplex virus type 1 & $181(75)$ & $168(70)$ & $0.76(0.51$ to 1.14$)$ \\
\hline
\end{tabular}

${ }^{*} \mathrm{P}=0.027$.

$\dagger P=0.004$.

rus, $T$ gondii, and $H$ pylori were detected by immunoenzyme assays (RADIM, Pomezia, Italy) according to the instructions. Vaccination against measles, mumps, and rubella became available in Italy in the 1980s and was very sporadically prescribed until the $1990 \mathrm{~s}^{18}$; therefore we consider antibodies to these viruses in our participants to be due to natural exposure.

\section{Statistical methods}

The association between each study factor and atopy was estimated by odds ratios. We used cumulative indexes of exposure (range none, any, and two or three) for microbes transmitted by food or the orofecal route ( $T$ gondii, hepatitis A virus, $H$ pylori) and for the remaining viruses (range 1 to 5 , no participant with 0 ); measles was excluded (prevalence close to $100 \%$ ). Confidence limits, $\chi^{2}$ tests, and tests for trend were calculated by Epi-info. The independent association of each study factor with atopy was estimated by odds ratio in a logistic regression analysis by adjusting for age (continuous variable) and for other variables (older and younger siblings, paternal schooling, population density) categorised as previously described. ${ }^{13}$ We performed a multiple regression analysis to determine changes in geometric mean values of concentration of total IgE in different groups, adjusting for age, older and younger siblings, paternal schooling, population density, and smoking habits. For multivariate analyses we used software from Biomedical Data Processing. ${ }^{19}$

\section{Results}

\section{Patterns of infections}

The prevalence of serum markers of microbes transmitted through the oral route was higher in the non-atopic than atopic participants, with statistical significance for $T$ gondii and hepatitis A virus (table 1 ) even after adjustment for each other and for $H$ pylori (not shown). Conversely, the presence of serum markers of all the six viruses transmitted by other routes was not associated with atopy (table 1).

\section{Dose response}

In an attempt to verify whether the microbial agents had a cumulative effect we created two gradients (indexes) as a measure of lifetime cumulative exposure 
Table 2 Atopy in 1659 Italian military cadets according to index of exposure to Toxoplasma gondii, Helicobacter pylori, and hepatitis A virus

\begin{tabular}{|c|c|c|c|c|c|c|}
\hline \multirow{2}{*}{$\begin{array}{l}\text { Index of } \\
\text { exposure }\end{array}$} & \multirow[b]{2}{*}{ No of participants } & \multirow{2}{*}{$\frac{\text { Absent atopy }(<0)^{\star} \dagger}{\text { No }(\%)}$} & \multicolumn{2}{|c|}{ Low atopy $(0 \text { to }<1.2)^{*}$} & \multicolumn{2}{|c|}{ High atopy $(\geqslant 1.2)^{*}$} \\
\hline & & & No $(\%)$ & Odds ratio $(95 \% \mathrm{CI}) \ddagger$ & No (\%) & Odds ratio $(95 \% \mathrm{CI}) \ddagger$ \\
\hline 0 & 796 & $494(62.1)$ & $142(17.8)$ & 1 & $160(20.1)$ & 1 \\
\hline 1 & 618 & $421(68.1)$ & $109(17.6)$ & 0.88 (0.66 to 1.18$)$ & $88(14.2)$ & $0.70(0.52$ to 0.94$) \S$ \\
\hline 2 or 3 & 245 & 181 (73.9) & 45 (18.4) & 0.87 (0.59 to 1.30$)$ & $19(7.8)$ & $0.37(0.22$ to 0.63$) \S$ \\
\hline
\end{tabular}

*Logarithm of ratio units=log (fluorescence units in sample/fluorescence units in reference serum).

†Reference group.

$\ddagger$ Adjusted for older and younger siblings, age, paternal education, and population density.

$\S \mathrm{P}$ for linear trend $=0.0001$.

to $T$ gondii, hepatitis A virus, $H$ pylori, and to mumps, rubella, chickenpox, herpes simplex virus type 1 , and cytomegalovirus; measles was excluded (prevalence exceeded 95\%). After adjusting for relevant sociodemographic confounders, the odds of being atopic decreased linearly with cumulative exposure to H pylori, $T$ gondii, and hepatitis $\mathrm{A}$ virus ( $\mathrm{P}$ for linear trend
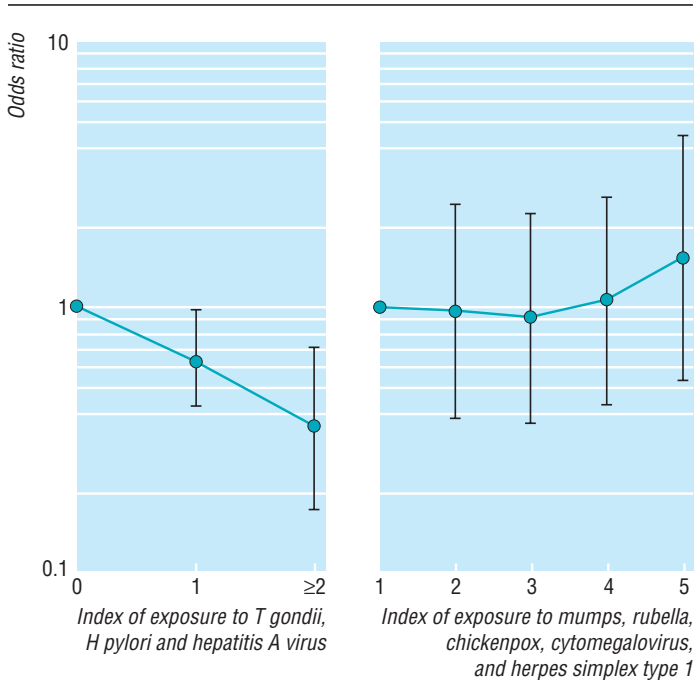

Fig 1 Adjusted odds of being atopic according to cumulative indexes of exposure to $T$ gondii, $H$ pylori, and hepatitis A virus ( $P$ for linear trend 0.0010 ) or to mumps, rubella, chickenpox, herpes simplex virus type 1 , and cytomegalovirus. Values were obtained in a multivariate analysis after adjusting for population density, paternal education, and number of older and younger siblings

Table 3 Skin sensitisation and respiratory allergies among 1659 Italian military cadets according to an index of exposure to Toxoplasma gondii, Helicobacter pylori, and hepatitis $A$ virus. Values are numbers (percentages) of participants unless stated otherwise

\begin{tabular}{|c|c|c|c|c|}
\hline & \multicolumn{3}{|c|}{$\begin{array}{l}\text { Index of exposure to orofecal and foodborne } \\
\text { infections }\end{array}$} & \multirow[b]{2}{*}{$P$ value } \\
\hline & $0(n=796)$ & $1(n=618)$ & 2 or $3(n=245)$ & \\
\hline \multicolumn{5}{|c|}{ Prevalence of sensitisation to allergens (weal $\geqslant 3 \mathrm{~mm}$ ) } \\
\hline Dermatophagoides pteronyssinus & $160(20.1)$ & $99(16.0)$ & $27(11.0)$ & 0.001 \\
\hline Cat & $68(8.5)$ & $38(6.1)$ & $6(2.4)$ & 0.001 \\
\hline Alternaria alternata & $15(1.9)$ & $10(1.6)$ & $1(0.4)$ & 0.140 \\
\hline Mixed grass & $118(14.8)$ & $75(12.1)$ & $21(8.6)$ & 0.008 \\
\hline Parietaria judaica & $65(8.2)$ & $53(8.6)$ & $12(4.9)$ & 0.212 \\
\hline Olea europaea & $21(2.6)$ & $15(2.4)$ & $3(1.2)$ & 0.255 \\
\hline Artemisia vulgaris & $14(1.8)$ & $9(1.5)$ & $1(0.4)$ & 0.151 \\
\hline \multicolumn{5}{|l|}{ Respiratory allergic disease } \\
\hline Allergic rhinitis (with or without asthma) & $123(15.5)$ & $82(13.3)$ & $16(6.5)$ & 0.001 \\
\hline Allergic asthma (with or without rhinitis) & $38(4.8)$ & $21(3.4)$ & $1(0.4)$ & 0.002 \\
\hline Total (allergic rhinitis or asthma) & $134(16.8)$ & $89(14.4)$ & $17(6.9)$ & 0.000 \\
\hline
\end{tabular}

$<0.001)$ but not with cumulative exposure to the other viral infections examined (fig 1).

In the whole population sample, the frequency of high atopy was 2.7 times higher $(20.1 \%$ v $7.8 \%$, $\mathrm{P}=0.00012$ ) among participants with no antibodies against $T$ gondii, $H$ pylori, and hepatitis A virus than among those with two or three positive results (table 2). Additionally, cumulative exposure to $T$ gondii, $H$ pylori, and hepatitis A virus was inversely related to skin sensitisation to all allergens tested, except $P$ judaica, and to allergic rhinitis or asthma (table 3). Interestingly, allergic asthma was diagnosed in only 1 of $245(0.4 \%)$ participants seropositive to at least two orofecal or foodborne infections ( $H$ pylori, $T$ gondii, hepatitis A virus) and allergic rhinitis was diagnosed in only 16 of $245(6.5 \%)$ versus 38 of $796(4.8 \%)$ and 123 of 796 $(15.5 \%)$ respectively in participants seronegative to $H$ pylori, $T$ gondii, and hepatitis A virus.

Exposure to orofecal and foodborne infections, total IgE concentration, and atopy

Geometric mean values for concentration of total $\operatorname{IgE}$ were only slightly higher $(\mathrm{P}=0.09)$ in participants not exposured to hepatitis A virus, $T$ gondii, and $H$ pylori, and this small difference tended to disappear after adjustment for atopy (table 4). Multivariate analysis, adjusted for relevant sociodemographic factors and atopy, confirmed that the cumulative exposure to $H$ pylori, T gondii, and hepatitis A virus was not associated with concentration of total IgE (not shown).

We plotted the percentages of participants with atopy against intervals of total IgE concentration on a log scale (fig 2). As expected, concentrations of total $\mathrm{IgE}$ were closely related to the prevalence rate of atopy in the whole population. The three other curves represent subgroups stratified according to index values of exposure to $T$ gondii, hepatitis A virus, and $H$ pylori. Interestingly, the prevalence of atopy increased with decreasing exposure to orofecal or foodborne infections within the three subgroups whose concentration of total $\mathrm{IgE}$ was between $160 \mathrm{kU} / \mathrm{l}$ and 1280 $\mathrm{kU} / \mathrm{l}$ (fig 2). For example, the frequency of atopic participants with concentrations between $160 \mathrm{kU} / 1$ and $320 \mathrm{kU} / \mathrm{l}$ was $28 \%$ (38 of 136) among those not exposured to $T$ gondii, hepatitis A virus, or H pylori, and only $8 \%$ (3 of 38) among those exposured to at least two of these infections.

\section{Discussion}

Mode of transmission of infections inversely associated with atopy

We found that atopy and respiratory allergies were inversely related to a gradient of exposure to orofecal 
or foodborne infections ( $T$ gondii, hepatitis A virus, and $H$ pylori) but not to viruses transmitted through other routes-that is, mumps, rubella, chickenpox, herpes simplex virus type 1 , and cytomegalovirus. The power of our study to detect an association between atopy and measles was limited by the high prevalence of this illness. It follows, however, that virtually none of our atopic participants had been "protected" against atopy by measles. Additionally, it is unlikely that the observed associations were confounded by low socioeconomic status because they persisted after adjustment for paternal education, which is strongly inversely associated with atopy in Italy. ${ }^{20}$

Hepatitis A virus is a typical orofecal infection, which is also acquired from contaminated food and water; $T$ gondii is acquired mainly through ingestion of unwashed raw vegetables contaminated by the faeces of infected mammals (mainly cats) and meat containing tissue oocysts $^{21} ; H$ pylori has been cultured from human faeces, ${ }^{22}$ house flies,${ }^{23}$ and sheep milk, ${ }^{24}$ and intrafamilial early cross infection through the faecal to oral or oral to oral route or by ingestion of contaminated food and water has also been suggested. ${ }^{22}{ }^{25}$ By contrast, measles, mumps, rubella, and chickenpox are highly infectious airborne viruses the transmission of which is less affected by hygiene. Herpes simplex virus and cytomegalovirus are acquired mainly through prolonged person to person contacts.

To our knowledge, we present the first epidemiological evidence that orofecal and foodborne microbes are better candidates than airborne respiratory viruses as determinants of an atopy "protective" effect.

\section{Lymphoid sites}

This study suggests that gut associated lymphoid tissue is the site where immune deviation in the response to common airborne allergens is influenced by adequate exposure to microbes. Animal models lend biological plausibility to this interpretation: in the mouse, gut flora is essential in postnatal preferential enhancement of $\mathrm{T}$

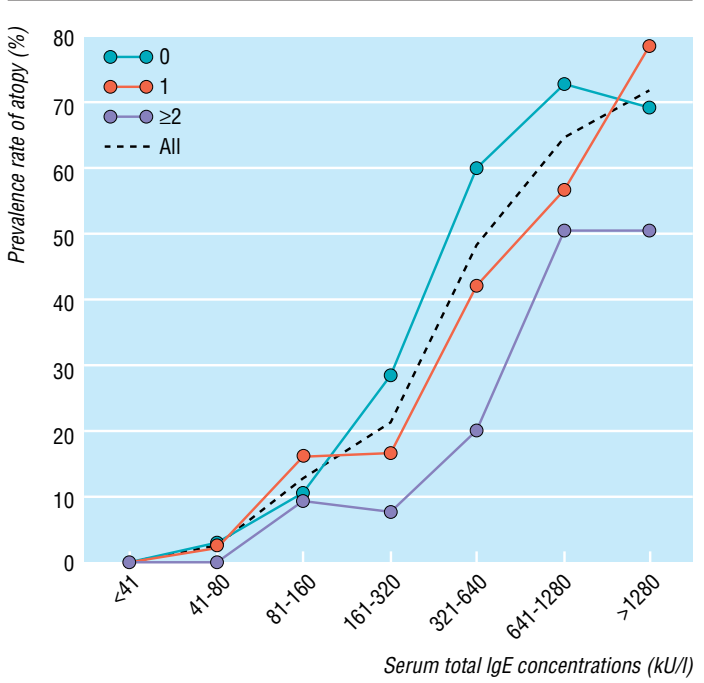

Fig 2 Relation between total IgE concentration and atopy according to cumulative exposure to $T$ gondii, $H$ pylori, and hepatitis A virus in 1659 Italian military cadets. Atopy is shown as the percentage of participants, grouped according to IgE concentration, who had a high concentration of specific IgE against airborne allergens
Table 4 Concentrations of total IgE among 1659 Italian military cadets according to atopy and an index of exposure to Toxoplasma gondii, Helicobacter pylori, and hepatitis $A$ virus. Values are geometric mean (SD) unless stated otherwise

\begin{tabular}{|c|c|c|c|c|}
\hline \multirow[b]{2}{*}{ Index of exposure } & \multicolumn{4}{|c|}{ Total IgE concentration ( $\mathrm{kU} / \mathrm{l})$} \\
\hline & All & $\begin{array}{l}\text { Absent atopy } \\
(<0)^{*}\end{array}$ & $\begin{array}{c}\text { Low atopy } \\
(0 \text { to }<1.2)^{*}\end{array}$ & $\begin{array}{l}\text { High atopy } \\
(\geqslant 1.2)^{*}\end{array}$ \\
\hline & $\mathrm{n}=1659$ & $\mathrm{n}=1096$ & $\mathrm{n}=296$ & $\mathrm{n}=267$ \\
\hline 0 & $88.9(4.5)$ & $45.7(3.6)$ & $158.1(3.1)$ & $417.8(2.5)$ \\
\hline 1 & $76.9(4.1)$ & $49.0(3.5)$ & $123.3(3.0)$ & $371.5(2.7)$ \\
\hline 2 or 3 & $74.5(3.8)$ & $50.2(3.3)$ & $177.4(2.9)$ & $423.6(2.5)$ \\
\hline F value† & 2.37 & 0.53 & 2.30 & 0.47 \\
\hline$P$ value & 0.09 & 0.59 & 0.10 & 0.62 \\
\hline
\end{tabular}

*Logarithm of ratio units=log (fluorescence units in sample/fluorescence units in reference serum). †From analysis of variance.

helper 1 immunity toward environmental antigens ${ }^{26}$; intestinal bacteria regulate $\operatorname{IgE}$ isotype switching in rats $^{27}$; T helper 2 responses of germ free mice are not susceptible to oral tolerance induction ${ }^{28}$; and reconstitution of intestinal microflora or oral administration of microbial substances (lipopolysaccharide) restore this susceptibility so preventing atopy. ${ }^{26}{ }^{28}$

Consistent with these animal models our data also suggest that microbes need not cause disease to exert a protective effect against atopy. For example, most cases of postnatal acquisition of $T$ gondii are subclinical, but $T$ gondii strongly stimulates dendritic cells to produce in vivo interleukin $12,{ }^{29}$ a key molecule in the deviation of $\mathrm{T}$ cell responses toward the TH1 phenotype. ${ }^{26}$ Our study does not, however, rule out that airborne bacteria which induce disease such as mycobacterium tuberculosis, ${ }^{6}$ or inhaled bacterial substances (endotoxins), ${ }^{26}$ may help to prevent respiratory allergy by stimulating other sites (for example, bronchial associated lymphoid tissue, Waldayer's ring, and related lymph nodes).

\section{Effects of diet and animals on atopy}

Our data may shed light on the role of diet in the allergy and asthma epidemic. They support the hypothesis that daily ingestion of traditionally processed food, not treated with antimicrobial preservatives and not subjected to hygienic procedures, may help to prevent atopy. ${ }^{1230}$ A traditional or "unhygienic" diet may act either by providing adequate daily microbial stimulation of the mucosal immune system (for example, Mycobacteria spp), ${ }^{31}$ or by favouring gut colonisation and high turnover of appropriate commensals (for example, enterobacteriaceae, Lactobacillus spp). ${ }^{15} 16$

Our results also impinge on the controversial debate as to whether close contact with domestic animals (dogs and cats) affords protection against allergy. ${ }^{32}$ The inverse relation between $T$ gondii and atopy may imply that higher exposure to microbes and their antigens released by animals may prevent atopy, a hypothesis borne out by studies of farmers' children. ${ }^{33}$ Caution should, however, be exercised because early exposure to pets in an hygienic context can facilitate specific IgE sensitisation to their allergens in predisposed people.

Time frame of balance between infections and atopy Although the infections examined are usually acquired in infancy, it was not possible to determine how early the cadets became infected. We do not, however, necessarily attribute a direct causal role to $H$ pylori, hepatitis A virus, or $T$ gondii in the observed lower risk of atopy. Rather, we consider that seropositivity to these 


\section{What is already known on this topic}

Investigations of the atopy "preventing" effect attributed to some airborne respiratory infections have produced conflicting data thus challenging the hypothesis that hygiene is causing the allergy and asthma epidemic in western countries

Studies in animals showed that microbes that prevent atopy may be those stimulating gut associated lymphoid tissue

\section{What this paper adds}

This case-control study found that atopy was inversely related to markers of infections transmitted through the orofecal route or borne by contaminated hands or foods (Toxoplasma gondii, Helicobacter pylori, hepatitis A virus) but not to those mainly transmitted through other routes (measles, mumps, rubella, chickenpox, cytomegalovirus, herpes simplex virus type 1 )

The data support the hypothesis that in humans, as in rodents, inadequate stimulation by commensals or pathogens of gut associated lymphoid tissue, a critical site for maturation of the mucosal immune system, enhances the risk of atopy

We suggest that the features of a westernised lifestyle involved in the allergy and asthma epidemic include a westernised diet with its antimicrobial additives and low microbial content and the dramatic decline in the transmission of orofecal infection. More research is needed to confirm this scenario and to establish whether certain microbes or their molecules may be used to prevent atopy without causing infectious disease microbes is a very reliable proxy of being reared in an environment that provides a higher exposure to many other orofecal or foodborne microbes, which may exert effects that prevent atopy. Our data suggest that appropriate microbial stimulation in people exposed to $T$ gondii, hepatitis A virus, or $H$ pylori may have prevented atopy completely in early infancy or, in some participants, it may have acted later to prevent a low subclinical sensitisation that started during childhood from increasing during adolescence and triggering allergic respiratory symptoms.

Thus we hypothesise that prevention of the atopic tendency may not be dichotomous (a yes or no event) or limited exclusively to a certain "window" period (very early in life). Rather it may be a dynamic and quantitative process extending at least to adolescence and subjected to genetic factors that regulate how early and intense must a continuous microbial exposure be to afford permanent protection from atopic sensitisation or to delay its onset. ${ }^{12}$

\section{Independent associations of total IgE concentration} and hygiene with atopy

We found that exposure to T gondii, H pylori, and hepatitis A virus was inversely associated with atopy but not with concentrations of total IgE. This confirms that concentration of total IgE is subjected to regulatory mechanisms and environmental influences distinct from those of specific IgE ${ }^{34}{ }^{35}$ Interestingly, even participants with only moderately high concentrations of total $\mathrm{IgE}$ were more frequently atopic if never exposed to the orofecal or foodborne infections examined.

In the absence of helminth infection, which strongly induce polyclonal and specific IgE responses, concentra- tions of total $\operatorname{IgE}$ are significantly determined by genetic factors. Consequently, our data suggest that the level of individual genetic predisposition required to develop significant atopic responses decreases parallel to exposure to orofecal or foodborne microbes. We speculate that similar curves would be observed in a population developing from a traditional to a western lifestyle. A practical implication is that the cut off point (if any) for a "normal" concentration of total IgE probably decreases with progressive westernisation. We anticipate, however, that in rural areas of developing countries where orofecal or foodborne infections are associated with heavy helminth infection, the relations reported in this study may be only partially reproduced. ${ }^{36}$

\section{Conclusions}

The decline of orofecal and foodborne infections and changes in the overall pattern of commensals and pathogens that stimulate gut associated lymphoid tissue may be strong determinants of the epidemic of allergic rhinitis and asthma in developed countries. Although further studies are required to verify this conclusion, it is not inconceivable that we may soon use certain microbes or their molecules to prevent atopy without causing infectious disease. ${ }^{31}$

We thank M Szklo for helpful discussion, A Palermo, R Vitalone, A Di Pietro, and A Rossi for technical assistance during data collection, Dr P Chionne for assistance in testing hepatitis A virus antibodies, Mrs Jean Gilder for reviewing and editing the English, and the military cadets of the non-commissioned officers'school in Caserta for participating in this study.

Contributors: PMM designed the study, coordinated data collection and serum allergy assays, and wrote the initial draft of the manuscript. MR was responsible for testing hepatitis A virus antibodies. SR, assisted by MF, was responsible for all the others serological assays of infectious markers. FR assisted PMM in study design and was responsible for statistical analysis together with LF. SB and FR assisted PMM with data discussion and the preparation of the final draft of the manuscript. PMM and FR will act as guarantors for the paper.

Funding: Italian armed forces 3001-96/97.

Competing interests: None declared.

1 Strachan DP. Hay fever, hygiene and household size. BMJ 1989;299:125960 .

2 Martinez FD. Role of viral infections in the inception of asthma and allergies during childhood: could they be protective? Thorax 1994;49:118991.

3 Holt PG. Infections and the development of allergy. Toxicol Lett 1996:86:199-203.

4 Strachan DP. Lifestyle and atopy. Lancet 1999;353:1457-8.

5 Shaheen SO, Aaby P, Hall AJ, Barker DJP, Heyes CB, Shiell AW, et al. Measles and atopy in Guinea-Bissau. Lancet 1996;347:1792-6.

6 Shirakawa T, Enomoto T, Shimazu S, Hopkin JM. The inverse association between tuberculin responses and atopic disorder. Science 1997;275:77-9.

7 Martinez FD, Stern DA, Wright AL, Taussig LM, Halonen M and the Group Health Medical Associates. Association of non-wheezing lower respiratory tract illnesses in early life with persistently diminished serum IgE levels. Thorax 1995;50:1067-72.

8 Bodner C, Godden D, Seaton A (Aberdeen WHAESE Group). Family size, childhood infections and atopic diseases. Thorax 1998;53:28-32.

9 Alm JS, Lilja G, Pershagen G, Scheynius A. Early BCG vaccination and development of atopy. Lancet 1997;350:400-3.

10 Strannegard IL, Larsson LO, Wennergren G, Strannegard O. Prevalence of allergy in children in relation to prior BCG vaccination and infection with atypical mycobacteria. Allergy 1998;53:249-54.

11 Von Mutius E, Illi S, Hirsch T, Leupold W, Keil U, Weiland SK. Frequency of infections and risk of asthma, atopy and airway hyperresponsiveness in children. Eur Resp J 1999;14:4-11.

12 Matricardi PM. Infections preventing atopy: facts and new questions. Allergy 1997;52:879-82.

13 Matricardi PM, Rosmini F, Ferrigno L, Nisini R, Rapicetta M, Chionne P, et al. Cross-sectional retrospective study of prevalence of atopy among Italian military students with antibodies against hepatitis A virus. BMJ 1997;314:999-1003.

14 Matricardi PM, Rosmini F, Rapicetta M, Gasbarrini G, Stroffolini T. Atopy, hygiene and anthroposophic lifestyle. Lancet 1999;354:430.

15 Wold AE. The hygiene hypothesis revised: is the rising frequency of allergy due to changes in the intestinal flora? Allergy 1998;53(suppl 46);20-5. 
16 Bjorksten B, Naaber P, Sepp E, Mikelsaar M. The intestinal microflora in allergic Estonian and Swedish 2-year-old children. Clin Exp Allergy 1999;29:342-6.

17 Matricardi PM, Nisini R, Biselli R, D'Amelio R. Evaluation of the overall degree of sensitization to airborne allergens by a single serologic test: implications for epidemiologic studies of allergy. J Allergy Clin Immunol 1994:93:68-79.

18 Gruppo di Studio Interdisciplinare Solle Vaccinazioni dell'età Evolutiva. Le vaccinazioni in Italia. Milano: Centro Informazione Scientifica Editore, 1996.

19 Dixon WJ, ed. BMDP statistical software, vol 2. Berkeley: University of California Press, 1990.

20 Matricardi PM, Franzinelli F, Franco A, Caprio G, Murru F, Cioffi D, et al. Sibship size, birth order, and atopy in 11,371 Italian young men. J Allergy Clin Immunol 1998; 101:439-44.

21 Beaman MH, McCabe RE, Wong S, Remington JS. Toxoplasma gondii. In: Mandell GL, Bennett JE, Dolin R. Principles and practice of microbial diseases, 4th ed. New York: Churchill Livingstone, 1995:2455-75.

22 Goodwin CS, Mendall MM, Northfield TC. Helicobacter pylori infection. Lancet 1997;349:265-9.

23 Grubel P, Huang L, Masubuchi N, Stutzenberger F, Cave DR. Detection of Helicobacter pylori DNA in houseflies (Musca domestica) on three continents. Lancet 1998;352:788-9.

24 Dore MP, Sepulveda AR, Osato MS, Realdi G, Graham DY. Helicobacter pylori in sheep milk. Lancet 1999;354:132.

25 Dominici P, Bellentani S, Di Biase AR, Saccoccio G, Le Rose A, Masutti F, et al. Familial clustering of Helicobacter pylori infection: population based study. BMJ 1999;319:537-41.

26 Holt PG, Sly PD, Bjorksten B. Atopic versus infectious diseases in childhood: a question of balance? Pediatr Allergy Immunol 1997;8:53-8.

27 Durkin HG, Chice SM, Gaetjens E, Bazin H, Tarcsay L, Dukor P. Origin and fate of IgE-bearing lymphocytes. II. Modulation of IgE isotype expression on Peyer's patch cells by feeding with certain bacteria and bacterial cell wall components or by thymectomy. J Immuno 1989;143:1777-83.

28 Sudo N, Sawamura S, Tanaka K, Kubo C, Koga Y. The requirement of intestinal bacterial flora for the development of an IgE production system fully susceptible to oral tolerance induction.J Immunol 1997;159:1739-45.

29 Reis e Sousa C, Hieny S, Scharton-Kersten T, Jankovic D, Charest H, Germain $\mathrm{RN}$, et al. In vivo microbial stimulation induces rapid CD40 ligandindependent production of interleukin- 12 by dendritic cells and their redistribution to T cell areas. J Exp Med 1997;186:1819-29.

30 Alm J, Swartz J, Lilja G, Scheynius A, Pershagen G. Atopy in children of families living with an anthroposophic lifestyle. Lancet 1999;353:1485-8.

31 Rook GAW, Stanford JL. Give us this day our daily germs. Immunol Toda) 1998;19:113-6.

32 Hesselmar B, Aberg N, Aberg B, Eriksson B, Bjorksten B. Does early exposure to cat or dog protect against later allergy development? Clin Exp Allergy 1999;29:611-7.

33 Braun-Fahrlander C, Gassner M, Grize L, Neu U, Sennhauser FH, Varonier HS, et al. Prevalence of hay fever and allergic sensitization in farmer's children and their peers living in the same rural community SCARPOL team. Clin Exp Allergy 1999;29:28-34.

34 Jarvis D, Chinn S, Luczynska C, Burney P. The association of family size with atopy and atopic disease. Clin Exp Allergy 1997;27:240-5.

35 Burney P, Malmberg J, Chinn S, Jarvis D, Luczynska C, Lai E. The distribution of total and specific serum IgE in the European community respiratory health survey. J Allergy Clin Immunol 1997:99:314-22.

36 Yemaneberhan H, Bekele Z, Venn A, Lewis S, Parry E, Britton J. Prevalence of wheeze and asthma and relation to atopy in urban and rural Ethiopia. Lancet 1997:350:85-90.

(Accepted 1 December 1999)

\title{
Reanalysis of epidemiological evidence on lung cancer and passive smoking
}

\author{
J B Copas, J Q Shi
}

\begin{abstract}
Objective To assess the epidemiological evidence for an increase in the risk of lung cancer resulting from exposure to environmental tobacco smoke.

Design Reanalysis of 37 published epidemiological studies previously included in a meta-analysis allowing for the possibility of publication bias.

Main outcome measure Relative risk of lung cancer among female lifelong non-smokers, according to whether her partner was a current smoker or a lifelong non-smoker.

Results If it is assumed that all studies that have ever been carried out are included, or that those selected for review are truly representative of all such studies, then the estimated excess risk of lung cancer is $24 \%$, as previously reported (95\% confidence interval 13\% to $36 \%, \mathrm{P}<0.001)$. However, a significant correlation between study outcome and study size suggests the presence of publication bias. Adjustment for such bias implies that the risk has been overestimated. For example, if only $60 \%$ of studies have been included, the estimate of excess risk falls from $24 \%$ to $15 \%$. Conclusion A modest degree of publication bias leads to a substantial reduction in the relative risk and to a weaker level of significance, suggesting that the published estimate of the increased risk of lung cancer associated with environmental tobacco smoke needs to be interpreted with caution.
\end{abstract}

\section{Introduction}

Exposure to environmental tobacco smoke (passive smoking) is widely accepted to increase the risk of lung cancer, but different epidemiological studies have produced varying estimates of the size of the relative risk. Hackshaw et al reviewed the results of 37 such studies that estimated the relative risk of lung cancer among female lifelong non-smokers, comparing those whose spouses (or partners) were current smokers with those whose spouses had never smoked. ${ }^{1}$ Of the 37 studies, 31 reported an increase in risk, and the increase was significant in seven studies. The remaining six studies reported negative results, but none of these was significant. Pooling these results using a method which allows for statistical heterogeneity between studies, Hackshaw et al concluded that there is an overall excess risk of $24 \%(95 \%$ confidence interval $13 \%$ to $36 \%){ }^{1}$ This is strong epidemiological evidence for an association between lung cancer and passive smoking $(\mathrm{P}<0.001)$.

The approach used by Hackshaw et al does not allow for the possibility of publication bias-that is, the possibility that published studies, particularly smaller ones, will be biased in favour of more positive results. We reanalysed the results and looked for evidence of publication bias.

\section{Methods and results}

The figure shows the relative risks from the 37 epidemiological studies analysed by Hackshaw et al $^{1}$ plotted against a measure of the uncertainty in that relative risk. This uncertainty (s) decreases as the size of the study increases so that large studies are on the left of the plot and small studies on the right. The plot shows a trend for smaller studies to give more positive results than the larger studies (correlation $=0.35$, $\mathrm{P}<0.05$, or $\mathrm{P}=0.012$ by Egger's test $\left.{ }^{2}\right)$. This graph is
Department of Statistics, University of Warwick, Coventry CV4 7AL $\mathrm{J}$ B Copas professor J Q Shi research fellow

Correspondence to: J B Copas jbc@stats.warwick. ac.uk

BMJ 2000;320:417-8 